\title{
Gender, Humour and Transgression in Canadian Women's Theatre
}

\section{Natalie Meisner, Donia Mounsef}

Are humour and laughter gender-specific? The simple answer, like most everything that is ideological, is "yes". Many feminists in recent years have grappled with the question of humour and how it is often the site of much contestation when it comes to women using it as a tool of transgression. This paper probes the seemingly timeless antipathy between humour and representations of femininity through recourse to performance and theories of the body. This article holds the term "woman" up to scrutiny while simultaneously examining the persistence of both critical and philosophical recalcitrance and the way humour continues to function in both gendered and violent ways. How does gender "do" or "undo" humour? Laughter is no simple matter for women, due to the legacy of profoundly polarized and hyper-sexualized historical ambivalence between femininity and laughter. Acknowledging the problematic nature of the category "woman", and after clearing some terminological distinctions (comedy, humour, irony, satire, and parody), this article investigates humour's complicated and volatile relationship to gender and the way the laughing body of women on stage presents a fascinating double helix of sexual aggression and power.

\section{Keywords}

Feminism; parody; humour; performance; Canadian Theatre; laughter; essentialism; gender

Q: How many feminists does it take to change a light bulb?

A: That's not funny!

"Isn't laughter the first form of liberation from a secular oppression? Isn't the phallic tantamount to the seriousness of meaning Perhaps woman, and the sexual relation, transcend it "first" in laughter."

Luce Irigaray, This Sex Which is not One (italics in original)

Are humour and laughter gender-specific? A question we often ask ourselves when thinking about comedy. The simple answer, like most everything that 
is ideological, is "yes". Many feminists in recent years have grappled with the question of humour and how it is often the site of much contestation when it comes to women. ${ }^{1}$ At a lecture at Vassar College, French feminist Monique Wittig was once asked if she had a vagina: she replied in the negative, triggering a legendary laughter response from the audience. This laughter may have been related to both the incongruity of the question, its unexpected response, and the fact that it was uttered by a radical feminist such as Wittig in a public forum. It may also have been related to the release of tension following what would've been a very tense moment when the curious spectator "popped" the essentialist question. Women and humour have had a complex history leading to more recent manifestations of this alliance with feminists such as Eve Ensler who wrote the Vagina Monologues because she was worried about "what we think about vaginas, and even more worried that we don't think about them" (3). Whether we think about vaginas or not, we are compelled to think about what humour does to gender and how gender "undoes" humour. As such humour is no simple matter for women, due to the legacy of profoundly polarized and hyper-sexualized historical ambivalence between femininity and laughter. Acknowledging the problematic nature of the category "woman", this paper will investigate humour's complicated and volatile alliance with gender and the way the laughing body of women on stage presents a fascinating double helix of sexual aggression and power. To illustrate this thorny and complicated relationship, after theorizing the three major approaches to laughter, this paper will examine the work of two Canadian playwrights spanning a century of comedy: Nellie McClung's Parliament of Women (1914) and Anne-Marie MacDonald's parody play Goodnight Desdemona, Good Morning fuliet (1988).

\section{Emancipatory Laughter}

When humourist Frances Whitcher quipped, in the mid-nineteenth century, that it was "a very serious thing to be a funny woman" she was speaking about the negative cultural reaction to female humourists, but also about the potential for self-definition and the erosion of gendered cultural constraints that laughter holds (in Walker xii). In Laughing Feminism: Subversive Comedy in Frances Burney, Maria Edgeworth, and Jane Austen, Audrey Bilger writes, "[r] ecent theories of feminist humour emphasize how humour can serve both as a psychological survival skill and an emancipatory strategy for women in 
a sexist society" (10). Critics such as Jane Flax and Terry Eagleton have pointed out that there is no singular dominant ideology that advances the ideals and values of a ruling class of culture. All ideologies, even those that represent themselves as uniform, are composite and conflict ridden. These internal contradictions are precisely the factors that render dominant ideologies like patriarchy open to contestation.

Nevertheless, being a funny woman has been problematic due to the supposed tension between intellect and femininity as well as the spatial restriction imposed upon women that was covered by the rhetoric of male and female "separate social spheres" in the nineteenth century. Whenever a woman breaks through a social barrier, she's making a feminist gesture of a sort, and every time a woman laughs, she's breaking unspoken rules that associate her with silence and passivity in public discourse. Laughter can both rupture a boundary and offer a necessary space for viewers to enter, "make a scene" and exit having left behind a pleasurable response.

The made for television film Iron fawed Angels (dir. Katja von Garnier, 2004) documents the struggle for women's suffrage in the United States by focusing on one of the key figures in the movement, Alice Paul (1885-1977). Following other suffragists, Alice Paul led a successful campaign for women's suffrage that resulted in 1920 in the $19^{\text {th }}$ Amendment of the US Constitution which gave women the right to vote. Paul's resolve in the cause of women's rights was legendary. She was undeterred by the beatings, solitary confinement, and force feedings she received while jailed for protesting the complacency of Woodrow Wilson's administration on women's suffrage. In 189o, when her plan to press for a federal constitutional amendment was opposed by Carrie Chapman Catt, president of the National American Woman Suffrage Association (Susan B. Anthony and Elizabeth Cady Stanton), Paul was so devastated that she considered giving up her work in the movement. It was the laughter provoked by her friend Lucy Burns that gave her the strength to return and build a coalition with NAWSA. Burns reminds Paul of an incident in England when they were hiding in a closet waiting to disrupt a session of parliament and Paul had to urinate. Burns dared Paul to pee in one of the Lord's boots which Paul gladly did, thus cementing their lifelong "subversive" relationship.

Arlene Plevin notes that "the subversive yet inviting tactic of humour" creates "an approachable and vulnerable persona that bridges distance, generation, even class" (227). Here Plevin is touching on one of the most fascinating aspects of laughter in the public sphere, namely that it can be 
used to avoid the traps of identity politics, and challenge barriers of race, class, and gender. A text that engenders laughter refuses realist or emotional foreclosure, as it is inevitably political and speaks in a compelling way to each new generation of women. Laughter creates a community by relying on shared pools of knowledge (called "scripts" in comedic studies) that both facilitate comedy's economy and re-inscribe women's history within and outside the canon.

While there might be emancipatory elements to any women's laughter, women's humour does not always qualify as feminist. Feminist humour, according to Regina Barreca, demands "that its audience share an awareness of women's oppression and a desire to reform an unjust system" (Quoted in Bilger 10). Further, Nancy Walker distinguishes between two streams of feminist humour: the first and most frequently occurring method to provoke feminist laughter is to make use "of a double text to pose a subtle challenge to the stereotype of the circumstance that the writer appears superficially merely to describe" (13). While the second type "more overtly confronts the sources of discrimination and has tended to emerge during periods of organized agitation for women's rights" (13). This type of humour may parody antisuffrage arguments (as we will see in our analysis of Parliament of Women) or posit a society in which women are powerful. In periods of social change, as Judy Little observes in Comedy and the Woman Writer, the work of writers who perceive themselves as "outsiders", or persons assigned to the threshold of power, will manifest "the distinctive features of inversion, mocked hierarchies, communal festivity, and redefinition of sex identity" (6). The work of such writers has the potential, according to Little, not only to mock the norm in a radical fashion, but also to generate new myths.

Susan Carlson's Women and Comedy, on the other hand, cautions the reader to take the equation of comedy and female power with a grain of salt. Comedy may be as essential to life as food and shelter, Carlson argues, and yet it can as easily be used to restrict women's power as to increase it. Carlson divides critics of comedy into two camps; those who hail comedy's inversion for its potential to upset established orders, and those who argue that these inversions simply ready the audience to accept the conventional happy ending which usually serves to reabsorb a female comic hero back into the social order through marriage or some other form of institutionalized reuptake. Carlson here follows Bakhtin in finding a basic ambivalence in the nature of carnival humour and rebellion that makes it "at once revolutionary and reactionary" (18). Social change, Carlson states, has no staying power if located in the 
liminal world where everything can return to order once the carnival ends, and in this way inversion serves a conservative function as it "underlines to members of the community that chaos is the alternative to cosmos, so that its better stick to the traditional order" (14).

How do women writers exploit the opportunities for emancipatory laughter that arise with comedic or carnivalesque breaks from tradition and then avoid the closure that is the hallmark of an even stronger return to a traditional order? Feminist humour can point out the internal contradictions in dominant ideologies, and engender laughter at the expense of a social order that keeps it in check by building a mode of address into a text that encourages laughter among women. Due to the complex social and cultural resistances to women's provocative laughter outlined above, there is often a critical neglect of funny women.

\section{Superiority, Incongruity, and Relief}

Before turning to the sites of comedic deployment in Canadian women's theatre, it may be useful to address the roots of the seeming antipathy toward funny women. According to the Hobbesian view of the laughter of superiority ${ }^{2}$, humour always implies a power relationship between the one telling the joke, the one laughing at it, and the one laughed at creating a network of inclusion and exclusion at the expense of the less powerful. Historically, women were not meant to wield the power of humour because that would violate social conventions that champion a male point of view, as Laura Mulvey pointed out in her landmark essay "Visual Pleasure and Narrative Cinema": "Woman then stands in patriarchal culture as signifier for the male other, bound by a symbolic order in which man can live out his phantasies and obsessions through linguistic command by imposing them on the silent image of woman still tied to her place as bearer of meaning, not maker of meaning" (6).

Similarly, in This Sex Which Is Not One, Luce Irigaray underlines the extent to which western philosophy depends upon repression of the feminine and works to "eradicate the difference between the sexes in systems that are self-representative of a "masculine subject" (74, emphasis in original). It is philosophical discourse itself that feminists must challenge and disrupt, notes Irigaray, otherwise it will continue to conceal the conditions under which its seemingly timeless masculine subject is reproduced and reinstalled. One of the most effective strategies used by women writers to resist the reinstallation of a universal 
male subject is to stage disruptions with the provocative laughter of feminist comedy. The topoi of laughter in literary studies, of course, is related to the terms comedy, humour, irony, satire, and wit; a relationship often resembling that of a disreputable cousin. The use of laughter as a critical approach to women's writing inevitably brings up the thorny issue of definition. This is not the main focus of this essay however, since, as Nancy Walker has noted, this kind of differentiation and the terminology has been "endlessly debated and definitions tend to vary according to disciplinary approach" (xii). Nevertheless, etymology of the word comedy continues to spark debate and as such it remains useful to introduce some of the possible meanings. The word comedy, many critics have pointed out, was derived from the Greek words cōma (sleep) and oide (song), or a night song, which would lend historical credence to the many modern equations between the comic and the oneiric. Sleep and laughter both relax inhibition and appeal to primary process thinking which is what prompted French philosopher Henri Bergson to devote many pages to the similarity between comic absurdity and dreams in his essay, Le Rire: "Essai sur la Signification du Comique" (1900). Sigmund Freud considered the two states so close that he referred to his essays on dreams and his essays on laughter as "twin brothers" (Complete 236). Laughter's unconscious drive and its potentially liberating force is also related to its ability to introduce double and triple discourses into the reception of what might otherwise be a straightforward text as we will see in our analysis of intertexuality in the dramatic work of Anne-Marie MacDonald. As such, laughter becomes the enemy of those individuals who wish to speak with unquestioned authority and absolute felicity, not just to their contemporaries, but for posterity.

Although the Hobbesian view that laughter stems solely from a feeling of superiority can be found at the bottom of many modern and contemporary views on comedy, this is not the view of Freud who argues, in fokes and their Relation to the Unconscious, that "the feeling of superiority bears no essential relation to comic pleasure" (196). Comic pleasure, he notes, is generated when an expectation creates mental energy that is then cut short by a surprise or a change in situation. The amount of energy that has been created to deal with the expectation is suddenly not required, creating an excess of pleasurable energy with no outlet and the mark of this excess pleasure is the laugh. Freud highlights laughter as a dual process that is at once profoundly corporeal and culturally inflected. ${ }^{3}$ Laughter may well be the very act that most clearly demonstrates the links between nature and culture, innovation and ritual. Mary Douglas, in her book Implicit Meanings: Essays in Anthropology, 
explains that jokes circulate in a similar fashion to rituals, insofar as they are acts that derive meaning from a cluster of socially legitimated symbols, much like a funeral. But jokes are capable of speaking back to stultifying or dogmatic rituals. A joke and the laughter that results can function as an anti-rite, mocking, parodying or deriding the naturalized processes of a given society. So intimately interwoven are the drives, desires, and motivations of bodies behaving within or against our cultural edifices that any wall aimed at containment is bound to fall before gales of laughter.

While laughter can be a tool for emancipation, this is not straightforwardly the case when wielded by women. Comedy provides a release for various anti-social instincts and can seek to confirm the status quo by denigrating a certain sector of society or laughing at the alleged stupidity of a social outsider. Freud believed that one of the important effects of laughter was to release aggressive/sexual feelings that might otherwise be suppressed. Why are women so often urged to be the ones who laugh at the joke, rather than crack it, even if the joke is at their own expense? While women are encouraged to respond to traditionally masculinist humour, the creation of humour by women, whether spoken, written, or especially performed, has provoked much controversy. And lastly, why are funny women who, instead of aiming their barbs at themselves or at other women, aim them at men, met with such hostility by dominant culture? Perhaps this is because, as Nancy Walker points out, humour is aggressive and, as such, "at odds with the conventional definition of ideal womanhood" (12).

This view began to shift somewhat in the nineteenth century when literary pursuits became more acceptable for women. The reading and writing of novels was considered a harmless pastime for women of leisure while the ability to write poetry - provided its content remained within certain parameters - was considered a mark of gentility and femininity. Funny writing, however, was differently received, especially when it is destined for live performance. This is likely because, according to Walker, "whether viewed from the perspective of psychology, anthropology, sociology or linguistics, humour is tied to power, autonomy, and aggression", all problematic stances for women (13). There are real material dangers for the woman who provokes laughter rather than responds to it for reasons that Walker explains:

The humourist is at odds with the publicly espoused values of the culture, overturning its sacred cows, pointing out the nakedness of not only Emperor, but also the politician, the pious, and the pompous. For women to 
adopt this role means that they must break out of the passive, subordinate position mandated for them by centuries of patriarchal tradition and take on the power accruing to those who reveal the shams, hypocrisies, and incongruities of the dominant culture. To be a woman and a humourist is to confront and subvert the very power that keeps women powerless, and at the same time to risk alienating those upon whom women are dependent for economic survival. (9)

The publication of Kate Sanborn's anthology The Wit of Women in 1885 was a direct response to the debate at the end of the nineteenth century about whether women possessed a sense of humour. Sanborn states that she published the book because she felt that anthologies of women's prose and poetry held a "general air of gloom" and "mawkish sentimentality and despair", while anthologies of humour contained no work by women. The problem, according to Sanborn was not that women only wrote in a despairing and humourless mode, but that they were encouraged to publish in this mode. The cultural antipathy to women's humour was so strong that if a woman wrote a funny book using her own name the public would often assume it had "really" been written by a man under a pseudonym.

This bias persists well into the twentieth century. Julia Klein interviewed a number of female comics for a 1984 Ms. Magazine article. "The women agree that stand-up comedy is, in itself, an aggressive act; making someone laugh means exerting control, even power. But a woman cannot come off as overaggressive or she will lose the audience" (Klein quoted in Barreca 126). Yet, exerting this power and control is less problematic for men for whom provoking laughter is often associated with the production of desire and pleasure, as laughter becomes a privileged signifier of "radically liberating dynamism", as Georges Bataille indicated. "Above knowable existences, laughter traverses the human pyramid like a network of endless waves that renew themselves in all directions... being itself... is spasmodically shaken by the idea of the ground giving way beneath its feet" (Bataille 176-177). This disruption of the body through laughter with its political potential is complicated for women who were denied its prospect and the pleasure associated with producing it.

Of course the "debate" about whether women have a sense of humour originated long before Bataille or Sanborn's anthology and is linked to those dogmatic centuries-long positions about whether women are in possession of souls, or hearts, or intellect, or reason, or whichever "organ" where a given 
society locates agency. The first production of Anna Cora Mowatt's play Fashion in 1845 was so raucously funny that it prompted a rash of irate critics to issue wholesale categorical statements denying women's sense of humour. An example of such condemnations can be found in W. Jones' remarks that "women have sprightliness, cleverness, smartness, though but little wit. There is a body and substance in true wit, with a reflectiveness rarely found apart from a masculine intellect. [...] We know of no one writer of the other sex, that has a high character for humour. [...] The female character does not admit of it" (333). Women have been oppressed by cultural forces that police their expression of aggression and/or eroticism. Consequently they are denied what Roland Barthes called "playful bliss" and the laughter response that comes from an erotically charged comic interplay. In The Pleasure of the Text, Barthes contends that a blissful "erotic" text needs to be celebrated for it is the site of radical ambiguity of a playful meaning-making processes and its very impossibility (15). Laughter in this case will not produce joy or the satisfaction of desire, but the indulgence in an ambiguous state of titillation, a pleasure often denied to women.

The ability of laughter to engender the expression of these states gives it great potential as an emancipatory strategy. This potential has not gone unnoticed by feminist scholars such as Mary Russo who outlined in her important essay "Female Grotesques: Carnival and Theory" the way that laughter can signify potential emancipation for women, yet simultaneously run the risk of having them aligned with "the demonic" or "the grotesque" (219). Russo's figure of the "unruly woman", as well as Bakhtin's notion of the carnivalesque which Russo builds on, are both extremely useful. The ambivalence that Russo perceives to be aimed at laughing women extends to other theories of laughter and comedy. In fact, not all theories of comedy see emancipatory potential in laughter due to the way that it can often function conservatively to police those who deviate from dominant social norms. Many theories of comedy, in fact, insist that laughter is exclusively a tool wielded by the powerful to punish the powerless. Simon Critchley's On Humour insists that our understanding of laughter as a valuable or positive phenomenon is unique to the modern period. Critchley usefully traces this shift to its source in three dominant theories of the causes of laughter: superiority, incongruity and relief. 


\section{Interrogating the Canon}

To illustrate this complex association between various types of laughter and their gendered expression, we will turn to two representative examples of Canadian women's theatre and performance. First, Suffragette Nellie McClung's celebrated Parliament of Women (1914) 4 was a brilliantly ludic play/ performance designed to challenge the Canadian government's exclusion of women from suffrage. By exploiting the liveness and theatrical opportunities of politics and parliament itself the play turns the superiority theory on its head by positing that what is presumed to be superior is in fact nothing more than the expression of absurd beliefs. The Dominion Elections Act of 1906 (echoing the Napoleonic Code) stated that "no woman, idiot, lunatic or criminal shall vote". Before Canadian Confederation (1867), the exclusion of women from voting was a "convention" rather than a law but when the British North America Act entrenched this exclusion, Canadian women were galvanized to action. The Canadian women's suffrage movement gained traction at the turn of the $2 \mathrm{O}^{\text {th }}$ century, under the influence of Prairie suffragette leaders such as Nellie McClung, Henrietta Muir Edwards, Louise McKinney, and Emily Murphy. McClung and other activists had been repeatedly told that "nice" women did not want the vote, by leaders such as the then Manitoba Premier, Sir Rodmond Roblin, who had characterized suffrage as a retrograde movement that would break up the home. McClung and her cohort scripted and staged a mock parliament at Winnipeg's Walker Theatre. Members of the equity league posed as delegations, appearing hat-in-hand requesting the right to vote and other concessions for men before a panel of women in power. McClung played the part of the Premier himself with considerable verve and with what, to all accounts, was a skillful vocal and physical impersonation of his grand deportment. She congratulated the men on their splendid appearance, but denied their request to participate in politics:

If men were all so intelligent as these representatives of the downtrodden sex seem to be it might not do any harm to give them the vote. But all men are not so intelligent. There is no use giving men votes. They wouldn't use them. They would let them spoil and go to waste. Then again, some men would vote too much... Giving men the vote would unsettle the home... The modesty of our men, which we reverence, forbids us giving them the vote. Men's place is on the farm... It may be that I am old-fashioned. I may be wrong. After all, men may be human. Perhaps the time may come when 
men may vote with the women - but in the meantime, be of good cheer. Advocate and Educate. (McClung, Purple Springs XXIII, online)

The evening was a smash success with two repeat performances playing to sold-out audiences. Many supporters were won for the cause and the proceeds from the ticket sales financed the rest of the Manitoba "Votes for Women" campaign. The application of humour to the supposedly dignified, objective edifice of the parliament effectively highlighted the way that such institutions disadvantaged women and looked after the interests of men under the mantle of objective benevolence. Using ironic and pamphletarian strategies, McClung reverses the expectations of her gender by emphasizing that irony is a disjunctive process between a message and its reception, and positioning the subject in a stance of uncertainty between possible overt and covert signification, unsettling patriarchy in the performance of patriarchy.

McClung reports in her book Purple Springs which recounts the events around the performance of Parliament of Women that a gentleman came to purchase a ticket for the show and was turned away by the man at the wicket who describes the women who are about to perform as "the sharpest-tongued things you ever listened to, and they have their speeches all ready. The big show opens tonight, and every seat is sold" (McClung, Purple Springs, XXII, online). As the curtain opens, a prelude description tells us in scathing commentary what the audience is about to see: "This is not the sort of Parliament we think should exist" [...] "this is the sort of Parliament we have at the present time - one sex making all the laws. We have a Parliament of women tonight, instead of men, just to show you how it looks from the other side. People seem to see a joke better sometimes when it is turned around" (McClung, Purple Springs, XXII, online). Turning the joke around is the first step toward interrogating the canon with a parodic distancing - what Linda Hutcheon called a "zero-degree counter discourse" or the Jamesonian repetition with critical distance that allows ironic signalling of difference at the very heart of similarity (185). The strategic moment of dialectical reversal, Schlegel's "permanent parabasis" or that moment when all the protagonists leave the stage and the chorus addresses the audience directly, is subverted in women's performance in a way that locates irony at the representational limits of politics, and interrogates the rhetoric of exclusion with alternative modalities of political action and resistance that show the flaws in a system based on arbitrary power. As men patronize women and denigrate their civil rights, McClung's women turn the political machine on its head showing that laughter 
in performance is a weapon of emancipation as the parabasis at the end of the play makes it clear. The final scene describes how the man (meant to be the premier of the Province), who came to watch the play, left "stung" by laughter and ridicule:

He hurried out into the brilliantly lighted street, stung by the laughter and idle words. His heart was bursting with rage, blind, bitter choking. He had been laughed at, ridiculed, insulted - and the men, whom he had made - had sat by applauding.

John Graham had, all his life, dominated his family circle, his friends, his party, and for the last five years had ruled the Province. Success, applause, wealth, had come easily to him, and he had taken them as naturally as he accepted the breath of his nostrils. They were his. But on this bright night in May, as he went angrily down the back street, unconsciously striking the pavement with his cane, with angry blows, the echo of the people's laughter in his ears was bitter as the pains of death. (McClung, Purple Springs, XXII, online)

While McClung challenged the superiority of men in Parliament of Women, and questioned naturalized categories of sex and gender with a scathing laughter, highlighting the absurdity of privilege, contemporary playwright Anne-Marie MacDonald's Goodnight Desdemona Good Morning fuliet (1988) takes on the theory of incongruity and relief by exposing how male privilege transforms women into the site of incongruous and deviant laughter. Set at Queens' University in Kingston, Ontario, the plot is simple: Assistant professor Constance Ledbelly is trying to prove that two Shakespearian tragedies were actually originally comedies that the Bard altered while embedding with a code - "the Gustav" - in order to hide their origin. Ledbelly turns to her colleague and mentor, Claude Night, to help crack the Gustav Code. Besides obsessing over the roots of the two tragedies, Constance conjectures that in both tragedies, there is the character that was elided, namely the "witty fool", in order to cleanse the tragedies from any comical element. Constance's doctoral thesis is accordingly titled: "Romeo and fuliet and Othello: The Seeds of Corruption and Comedy". This seed of corruption is also reflected in Constance's relationship to professor Night who allegedly published many of her work under his name resulting in his promotion to full professor at her expense, and making her the "witty fool" at the end of the play. The feminist aspects of this exploitative relationship are the division of labour between 
Ledbelly and Night and the fact that male academics are often promoted at the expense of their female counterparts.

Constance snaps when her mentor who has been exploiting her labour takes the job she thought was earmarked for her. The sudden shock of betrayal combined with a kind of feverish scholarly delirium plunge her bodily into the plot where she moves among the characters of Othello. There she finds a kind of sisterhood with Desdemona and in the following passage Constance explains her plight:

\section{CONSTANCE:}

It's quite dog eat dog. And scary too

I've slaved for years to get my doctorate,

But in a field like mine that's so well trod,

You run the risk of contradicting men

Who've risen to the rank of sacred cow,

And dying on the horns of those who rule

The pasture with an iron cud. (37)

What started as straightforward intertextuality becomes intra- or and transtextuality as Constance not only quotes the Bard, but illuminates the laminate relationship between gender and violence by appearing "in the flesh" in the play just at the moment Iago has provoked Othello in a fit of jealous rage.

OTHELLO: Had Desdemona forty thousand lives!

One is too poor, too weak for my revenge.

Damn her, lewd minx! Oh damn her! Damn her, O!

I will chop her into messes. Cuckold me!

IAGO: O, 'tis foul in her.

OTHELLO: with mine officer!

IAGO: That's fouler.

OTHELLO: Get me some poison, Iago, this night.

IAGO: Do it not with poison. (Iago hands a pillow to Othello) Strangle her in bed.

CONSTANCE: No! (Both Othello and Iago turn and stare at her, amazed) Um... you're about to make a terrible mistake... m'lord. (25)

At this moment, Constance gathers her courage and lunges forward grabbing the infamous "strawberry spotted handkerchief" that was the very thin (yet 
somehow damning proof) offered as proof of Desdemona's infidelity. Iago has been hiding it in his own trousers all along and in this moment he becomes suddenly undone, to great comic effect as the handkerchief is revealed. This reversal is highlighted even more when, immediately after her daring intervention, Constance's literary sensibilities take the stage. She realizes that in attempting to save the life of the woman, she has "wrecked" a masterpiece and so tries to contain the damage by stuffing the handkerchief back in Iago's pants and picking up the prospective murder weapon (a pillow) off the floor and giving it back to Othello.

Theatrical transformation makes this incongruous immersion possible, but also the ability to laugh at one's tragic predicament. However, as Shannon Hengen argues judiciously "to the extent that Constance is mocked, the play undermines its radical potential, but more importantly to the extent that Constance herself learns through other women to laugh at her oppressors and so reclaim her power, providing hopeful closure, the play shows progressive force" (99). As marginalized as she seems, Constance appears to retain a white, middle class privilege that puts her in the same category of those oppressors she purports to laugh at. However, the laughter that the play generates stems not out of a feeling of superiority but one of incongruity: Constance doesn't seem to benefit from that privilege, she is not publishing like her colleague and mentor, and her theories are at best eccentric. Her redemption, if there is one, is that her encounters with Desdemona and Juliet open her eyes to how exploited she is - she is "interpellated" (to use an Althusserian term) by the reality of her own oppression. Consequently, Constance "seems to have gained the necessary insight into her thesis topic to know how to conclude it as well. Having been just a fool at the play's opening, laughed at by the audience and other characters, she thus becomes the witty fool" (Hengen 102).

When asked why she continues to write comedies for the stage instead of tragedies, Anne-Marie MacDonald responded by articulating the potential for comedy to challenge stereotype and connect with an audience of diverse backgrounds:

You can go into more dangerous territory, or more challenging territory for the general audience than with something that isn't comedy. That is not a value judgment. [...] I happen to do the kind of comedy that I hope challenges but invites people of diverse backgrounds and identities to an experience that they might be prejudiced against at first. But I somehow 
am going to make it possible for them to enter an experience that they thought they had no sympathy for. And in the end they find themselves identifying with people who they thought were perverse or alien or deviant, and that's my crusade if I have one. (Quoted in Hengen 103)

It is this connection to an audience, and the potential to effect change through laughter that feminist theatre reassigns a different role to the comic and resists declaration of the end of comedy which have become the hallmark of postmodern positioning.

\section{Conclusion or Comedy's Post-Mortem}

These examples of feminist humour spanning a century remind us that what some have called "the death" or "the end" of comedy is simply comedy that dares to laugh at the magical relationship between the powerful and the powerless, between privilege and representation of privilege. In fact declarations of the "death of comedy" such as Segal's assertion that "after reaching its apogee with Figaro, comedy has nowhere to go but down" (403) are really a throw-back or a hang-over from the Hobbesian superiority theory. Rather than laugh at the patriarch, it seems, some critics would declare that comedy is dead and the only kind of laughter available to us bedraggled postmoderns is Beckett's moribund and exceptionally unfunny "risus puris". Susan Carlson elaborates, in Women and Comedy, how despondency has coloured comic theory in the last eighty years. Carlson states that Wolfgang Iser, for example makes "Beckett his standard of contemporary comedy" and hence succeeds in reading "the comic process as the decomposing of the individual" (17). Herbert Blau, Carlson further points out, considers contemporary comedy to be no more than "the laugh laughing at the laugh" (17). This grim, rather humourless, picture of humour presumes the dissolution of the subject and the end of pleasurable laughter. Outsider humour, of which feminist and women's humour is a part, tells us that we can laugh at the powerful. Even if feminist humour does not always produce transgressive politics per se, it does exploit political fault-lines introducing the possibility of unsettling gendered categories of laughter and endowing the subject with multiplicity and agency. 


\section{Notes}

1. It is important here to acknowledge that although this article deploys the categories of "woman", "man", "male", "female", "femininity", "masculinity", these of course are far from fixed categories. The category "woman" is, at the same time, a biological term, a contested site of materiality and politics, a performative practice, a representation, and a cultural convention. While the binary opposition of gender has been coming undone in the last four decades, its very opposition remains relevant when it comes to the way spectatorship functions. For that reason it is important today to continue to analyze how sexual difference is encoded in narrative and decoded in performance and to acknowledge the all-pervasive power of patriarchy even in a presumed post-gendered paradigm.

2. The history of this legacy of treating laughter with suspicion continued well beyond the Classical Greeks and was momentarily disrupted by the Italian Commedia dell'arte, where it became possible to mock and ridicule masculinity. The figure of Il Capitano for example, the cowardly captain of the Commedia, becomes a pathetic imitation of manliness whose ridiculous exploits are the subject of laughter. Such subversions manifested themselves later in the figure of the cuckold, the idiot, or the downtrodden male. But in general, mocking masculinity was considered taboo until the second half of the 20th century when hegemonic masculinist discourses came under scrutiny in feminist and gender variant discourses. 


\section{Works Cited}

Aristotle. Poetics. Trans. Kenneth McLeish. New York: Theatre Communications Group, 1999. Print.

Barthes, Roland. The Pleasure of the Text. Trans. Richard Miller. New York: Farrar Strauss and Giroux, 1975. Print.

Barreca, Regina. Last Laughs: Perspectives on Women and Comedy. New York: Gordon and Breach, 1988. Print.

Bataille, Georges. Visions of Excess: Selected Writings. Trans. Allan Stoekl, Carl

R. Lovitt and Donald M. Leslie. Manchester: Manchester University Press, 1985. Print.

Bergson, Henri. Laughter: an Essay on the Meaning of the Comic. Trans. Fred Rothwell. Project Gutenberg. 30 March 2014. <http://www.gutenberg. org/etext/4352>.

Bilger, Audrey. Laughing Feminism: Subversive Comedy in Frances Burney, Maria Edgeworth, and Jane Austen. Detroit: Wayne State University Press, 1998. Print.

Carlson, Susan. Women and Comedy: Rewriting the British theatrical Canon. Ann Arbor: University of Michigan Press, 1991. Print.

Critchley, Simon. On Humour. London: Routledge, 2002. Print.

Douglas, Mary. Implicit Meanings: Essays in Antropology. London: Routledge, 1975. Print.

Ensler, Eve. The Vagina Monologues. New York: Villard, 1998. Print.

Freud, Sigmund. The Complete Psychological Work of Sigmund Freud. Ed. James Strachey. London: The Hogarth Press, 1960. Print.

---. Fokes and their Relation to the Unconscious. Ed. James Strachey. New York: Norton and Company, 1960. Print.

Hengen, Shannon. "Towards a Feminist Comedy." Canadian Literature 146 (Autumn 1995): 97-109. "Herstory: An Exhibition", University of Saskatchewan. December 2013. <http://library.usask.ca/herstory/herstory. html>.

Hobbes, Thomas. Leviathan. London: Penguin, 1988. Print.

Homer. The Iliad. Trans. Robert Fitzgerald. New York: Doubleday, 1989. Print.

Hutcheon, Linda. A Theory of Parody: The Teachings of Twentieth-Century Art Forms. New York: Methuen, 1985. Print.

Irigaray, Luce. Speculum of the Other Woman. Trans. Gillian Gill. Ithaca: Cornell University Press P, 1985. Print. 
---. This Sex Which Is Not One. Trans. Catherine Porter. Ithaca: Cornell University Press, 1985. Print.

Iron jawed Angels. Dir. Katja von Garnier. HBO, 2004. Film.

Jones, W. A. “The Ladies' Library." Graham's Magazine 21 (1842): 333. Print.

MacDonald, Anne-Marie. Goodnight Desdemona Good Morning Juliet. Toronto: Vintage, 1988. Print.

McClung, Nellie. Purple Springs 1921. Project Gutenberg. 2 April 2014. <http:// www.gutenberg.org/cache/epub/10221/pg10221.html>.

Mulvey, Laura. "Visual Pleasure and Narrative Cinema." Screen 16.3 (Autumn 1975) 6-18. Print.

Plato. The Republic. 2nd ed. Trans. Desmond Lee. New York, NY: Penguin Books, 1987. Print.

Plevin, Arlene. "The Subversive Humor of Blue Vinyl." New Perspectives on Environmental fustice. Ed. Rachel Stein. Rutgers NJ, 2004. 225-239. Print.

Russo, Mary. "Female Grotesques: Carnival and Theory." Feminist Studies, Critical Studies. Ed. Teresa de Lauretis. Bloomington: University of Indiana Press, 1986. 213-229. Print.

Sanborn, Kate. "Introduction" to The Wit of Women. Linda Morris, American Women Humorists. New York: Garland Publishing, 1994. Print.

Segal, Erich. The Death of Comedy. Cambridge, MA: Harvard University Press, 2001. Print.

Showalter, Elaine. Hystories: Hysterical Epidemics and Modern Culture. New York: Columbia University Press, 1997. Print.

Walker, Nancy A. A Very Serious Thing: Women's Humor and American Culture. Minneapolis: University of Minnesota Press, 1988. Print.

Wittgenstein, Ludwig. Culture and Value. Ed. G.H. von Wright, trans. P. Winch, Oxford: Blackwell, 198o. Print. 